\title{
The function of the topos philophronesis in the letter to the Philippians - a comparison with three ancient letters of friendship
}

\author{
Elma Cornelius \\ Dept. Classics \& Semitics \\ Potchefstroom University for CHE \\ POTCHEFSTROOM
}

\begin{abstract}
The objective of this article is to determine the function of the tónos pidoxpounzos in the letter to the Philippians. According to Koskenniemi

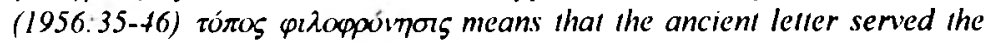
purpose of expressing the friendly relationship ben'een two persons. Koskennieni also idenifies typical philophronetic phrases and formulae. Because "l is expected that the tünos pidapavingos will be more prominent in letters of friendship (see Dahl, 1976:539), three papyri letters, which were classified by Stowers (1986:58-76) as letters of friendship, are analysed. The letter to the Phulippians is compared to the ancient epistolary practice when identifying and determining the function of the rónos pidoppointnos It is concluded that the róros pitappoingors serves the function of Ėous and $\pi \dot{\alpha}$ Ous and that the relationship between addresser and addressee can be determined by analysing the pidoppuinors.
\end{abstract}

\section{Introduction}

The aim of this article is to identify the (possible) presence of the tótos pizarpoinnors in the letter to the Philippians, to determine the function of such a topos and the relation between the topos and the túros of the letter.

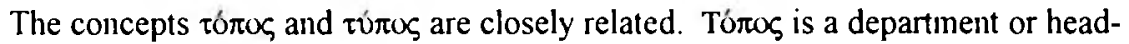
ing containing arguments of the same kind. Koskenniemi (1956:35-46) extrapolates three general characteristics of the Greek letter which he takes to be crucial to understanding the uniqueness, purpose and function of the Greek letter:

* The first and most important is the tómos yitoxpóvmors, which expresses the friendly relationship between two persons. 
* The second is the tómos $\pi \alpha$ ovvoía, meaning that the letter is intended to revive and sustain the existence of a friendship when the correspondents are physically separated.

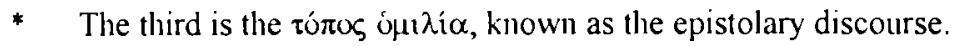

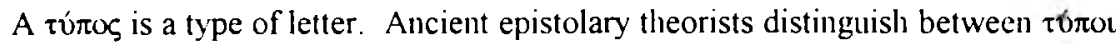
of letters according to their style. Cicero (Ad Iamiliares 2.4.If; 4.13.1, 6.10.4) distinguishes between simple letters with factual infonnation and letters communicating the mood of the writer, the genus familiare et iocosum and the genus

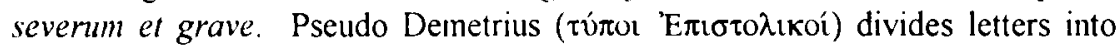

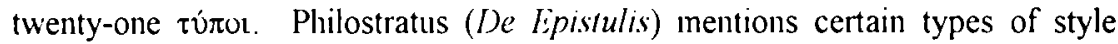
used in letters, Julius Vicior (Ars Rhetorica 27) distinguishes between litterae

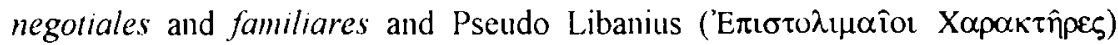

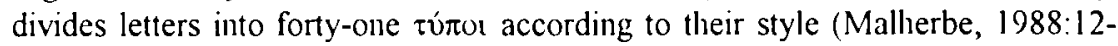
13).

On the basis of these ancient categories, modern epistolary theorists have developed and refined the possible $\tau$ tónor of ancient letters. Among the letter types discussed are letters of friendship, introduction, blame, reproach, consolation, criticism, censure, praise, interrogation, accusation, apology, gratitude, etc. (Doty, 1983:10; Stowers, 1986:51-174; White, 1986:193-198).

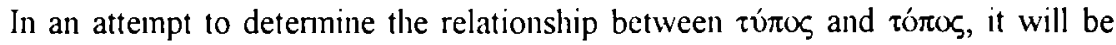
fruitful to notice that, according to Dahl (1976:539), tó mainly in the opening and closing segments of a letter and is most elaborate in letters of friendship and diplomatic correspondence. It thus seems possible to

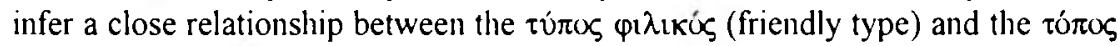
$\varphi \imath \lambda o p p o ́ v m \sigma \varsigma$ (friendly relationship).

Stowers (1986:60) classifies the letter to the Philippians as a letter that employs tónot and language from the friendly letter tradition. Does Stowers mean that

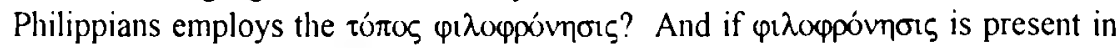
Philippians, how does it function? What is the relationship between the tónos

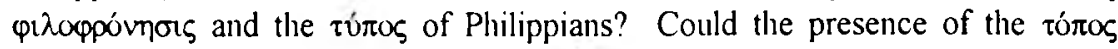
$\varphi 1 \lambda o x p o ́ v \eta n$ s mean that Philippians is a friendly letter? In order to answer these kinds of questions, the following will be done:

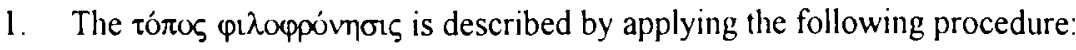

* Ancient epistolary theorists and rhetoricians are consulted.

* Modern theorists are consulted on the ancient epistolary practice.

* A practical epistolographical analysis of a sample of ancient letters is attempted. 
2. The letter to the Philippians is compared to ancient epistolary practice when identifying and determining the function of the tóros pizocpóvmors.

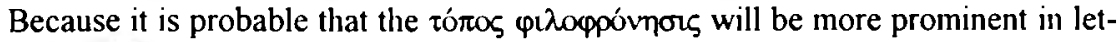
ters of friendship (see Dahl, 1976:539), three papyri letters, classified by Stowers (1986:58-76) as letters of friendship and written between 95 B.C.E. and 58 C.E. are analysed.

The ancient theories and - practice of epistolography and rhetoric date from 200 B.C.E. . Because the letter to the Philippians was possibly written between 52 C.E. and 61 C.E., it seems justified to interpret it in comparison with the three papyri letters from a rhetorical - and epistolographical perspective, since all these letters were written within societies which applied the same rhetorical - and epistolographical rules. These letters as well as the letter to the Philippians are formally analysed according to the theories of White $(1972,1986)$.

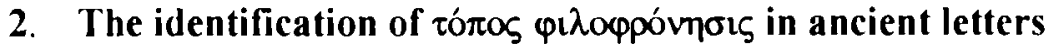

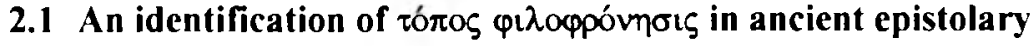 theorists and rhetoricians}

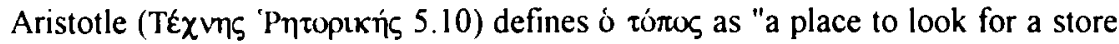
of something, or the store itself; a heading or department, containing a number of rhetorical arguments of the same kind". Tómot are of two kinds: Korwoi tótol or

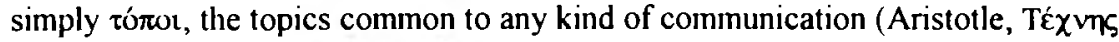

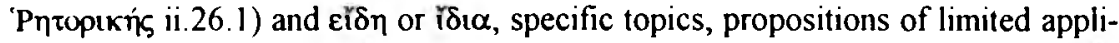

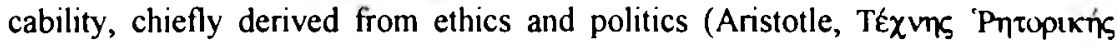
i.2.21).

Cicero (Topica) defines a tómos as a residing place of arguments and distinguishes between inherent tótol ( connection) and extrinsic rómor (arguments not invented by the art of the orator) (Murphy, 1972:146-147).

Quintilian defines the tótur for arguments as those areas of the mind to which one may go for specific sources of proof (Quintilian, Institutio Oratoria 5.10).

Although the ancient rhetoricians do not deal with the róros pidoppóvnors as such, Aristotle refers to something similar when he deals with Evvex wor. When inventing a speech (or any other vehicle of communication), one uses either

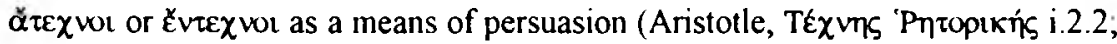

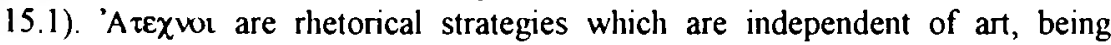
already in existence and ready for use - rhetorical strategies such as witnesses 


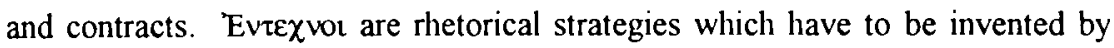

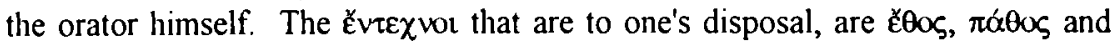

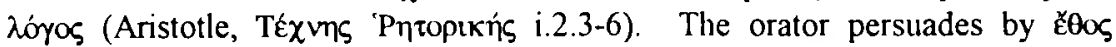
(moral character), when the speech is delivered in such a manner as to make the speaker worthy of confidence. When one persuades by $\pi \alpha \dot{\alpha} \theta \varsigma_{\zeta}$, one persuades by means of the hearers, by addressing their emotions. Lastly, persuasion is produced by the speech itself, called the zópos.

When the orator chooses, for instance, to persuade by $\pi \alpha \theta_{0}$, he must provide

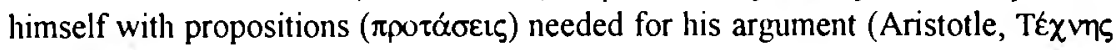

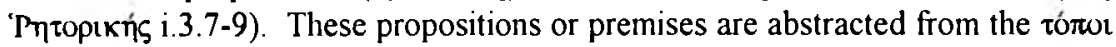
to his disposal. Premises that are common to all fields, types of speeches and characters of speakers are premises such as the possible and impossible

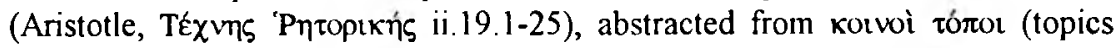
common to all kinds of rhetoric). Premises abstracted from हैं $\delta \eta$ (specific topics)

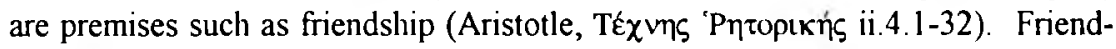
ship and other $\varepsilon i \check{\delta} \eta$ are discussed by Aristotle as premises for establishing $\check{\theta} \theta \circ$ s and $\pi \alpha \dot{\alpha} \theta \circ$ (

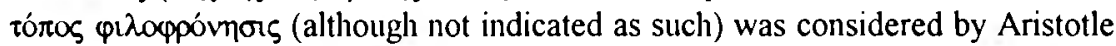

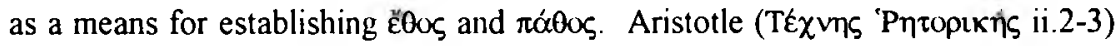
is of opinion that it makes a great difference with regard to producing conviction that the speaker should reveal himself to be possessed of certain qualities and that his hearers should think that he is disposed in a certain way towards them; and further that they themselves should be disposed in a certain way towards him.

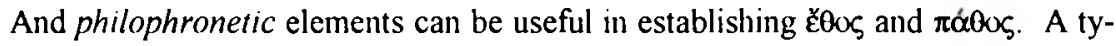
pical example of such a use is: I know you 're worried about our friend Peter's health, but I want to assure you that we all remember him in our prayers. In this way the writer is convincing his hearers that they have mutual concens; and where can a better way be found than to say it by an expression of mutual remembrance (see 2.1)?

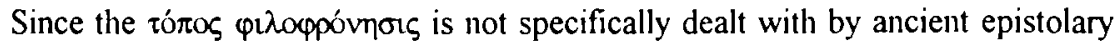
theorists and ancient rhetoricians, it will be fruitful to look at the practice of ancient letter writing. This practice is described by modern theorists such as Dahl (1976) and Koskenniemi (1956).

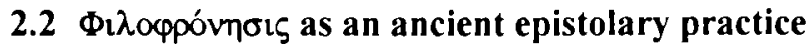

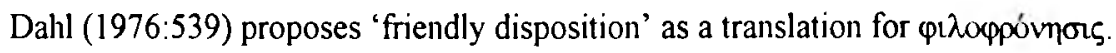
He states that philophronetic statements often prepare the way for expressions of disappointment, embarrassment, reproach, irony or warnings resulting from the friendship. 


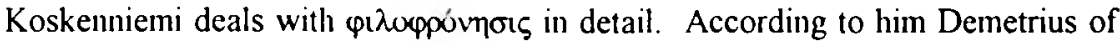
Phalerum views a letter as a postulation of friendship, and that is why he considers the friendly disposition as the most important essence of the letter and he mentions this function of the letter as being fundamental (Koskenniemi, 1956:35, 37).

Because Koskenniemi (1956:1-214) bases his study on ancient epistolary practice, and does a detailed study of philophronetic statements, his research will be summarized here. Koskenniemi (1956:128-154) considers the following as typical philophronetic phrases and formulae:

* General expressions of concern about the recipient's welfare

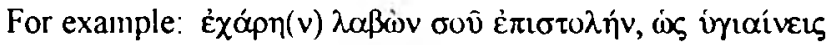

"I rejoiced at receiving your letter, that you are well".

* Formula valetudinis

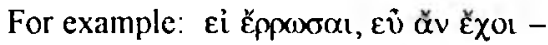

"If you are well, I would be delighted".

* Proskynema formula

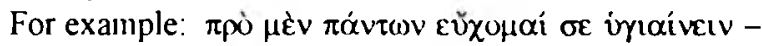

"Above all I pray that you are well".

* Mutual remembrance

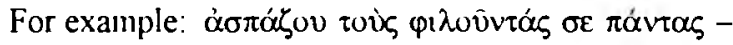

"Give my regards to everybody who loves you".

* Greetings

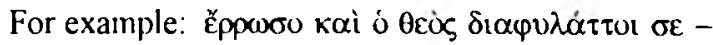

"Be well and may God be with you".

* Closing clause/paragraph

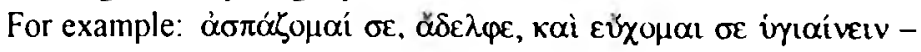
"I salute you, brother, and pray that you are well".

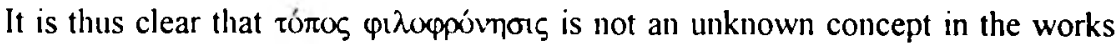
of modern epistolary theorists - works which are mere descriptions of the ancient

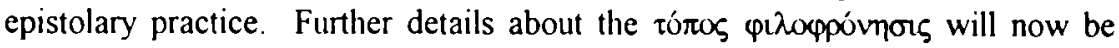
identified by means of an analysis of ancient friendly letters.

\subsection{A practical analysis of a sample of ancient letters}

In order to see how pidurpórmors functions in ancient letters, the following ancient letters will be analysed with the help of infonmation given by Koskenniemi (1956:128-154) on philophronetic statements and fonnulae: PMert (A Descriptive Catalogue of the Greek Papyri in the Collection of Wilfred Merton) I 12, Ex Hercul (Excavations of Herculaneum) 176, and SelPap (Select Papyri) I. 


\subsubsection{Papyri Merton I 12: A letter to Dionysios the physician (58 C.E.)}

This is a letter of Chairas to his friend Dionysios, a physican. The text and translation are from White (1986:145-146).

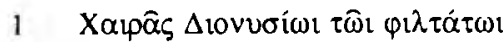

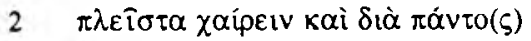

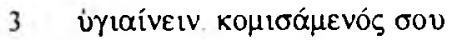

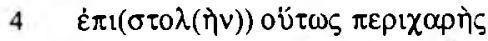

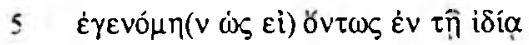

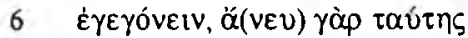

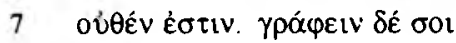

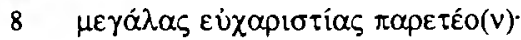

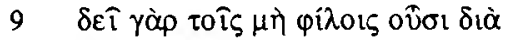

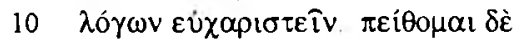

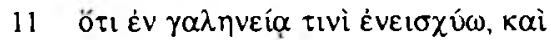

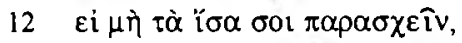

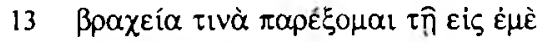

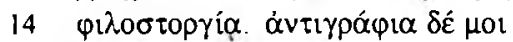

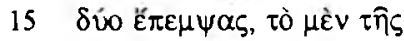

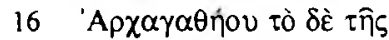

$17 \dot{\varepsilon} \lambda \kappa \omega \tau 1 \kappa \hat{\eta} \zeta . \dot{\eta} \mu \dot{\varepsilon} v^{\prime A} \mathrm{~A} \rho \chi \alpha \gamma \dot{\alpha} \theta 1 \zeta$

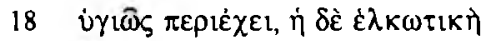

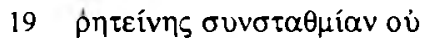

$20 \pi \varepsilon \rho \varepsilon^{\prime} \chi \varepsilon l . \dot{\varepsilon} \rho \omega \tau \hat{\omega} \delta \varepsilon \dot{\varepsilon} \sigma \varepsilon \pi \varepsilon p i$

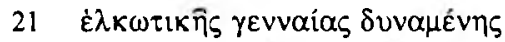

$22 \dot{\alpha} \kappa \delta \mathrm{v} \delta \delta \dot{v} v \omega \varsigma \pi \dot{\varepsilon} \lambda \mu \alpha \tau(\alpha) \dot{\varepsilon} \lambda \kappa \hat{\omega} \sigma \alpha \mathrm{l}$

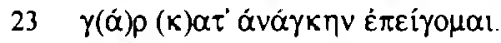

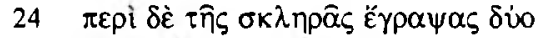

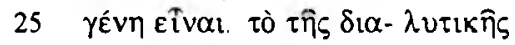

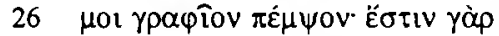

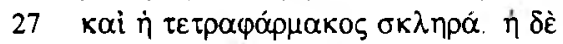

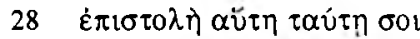

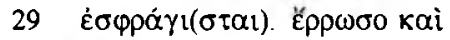

$30 \mu \varepsilon \dot{\mu} \mu \nu \eta \sigma 0 \tau \hat{\omega} v \varepsilon \dot{\varphi} \uparrow \eta \mu(\varepsilon \dot{\varepsilon} v \omega v)$

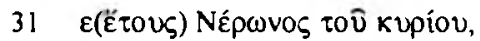

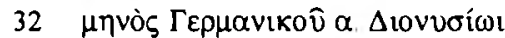

33 i $\alpha \tilde{\omega} \omega$
Chairas to his dearest Dionysios many greetings and continual good health. When I received your letter, I was as exceedingly joyous as if I had actually been in my own native place; for without (the joy of) that there is nothing. And I can disregard writing to you with great gratitude, for it is (only) required that one expresses thankfulness with words to those who are not friends I am confident that I can persevere with sufficient tranquillity, and if not able to render something equivalent, I will be able to render some humble return for your warm affection towards me. You sent two prescription copies, one of the Archagathian, the other of the caustic plaster The Archagathian is of the right consistency (rightly compounded), but the caustic does not include the correct amount (relative weight) of resin I request your advice regarding a suitable caustic that can be used safely to cauterize the soles of the feet; for I am pressed by necessity (for a prescription). Regarding the stiff plaster, you wrote that there are two kinds Send the prescription of the resolvent type; for the fourdrug plaster is also stiff. This letter for you is sealed with this (?). Good-bye and remember what I have said (Year) 5 of Nero the lord, the month of Germanicus I 


\subsubsection{The identification of philophronetic elements in PMert I 12}

In order to determine the function(s) of pitoopónmors, typical philophronetic elements will be identified within the different parts of the letters. The analysis (in each case) is my own, while infornation provided by White (1986:198-212) was found useful.

\section{* Letter opening}

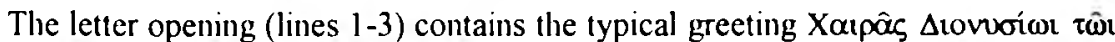

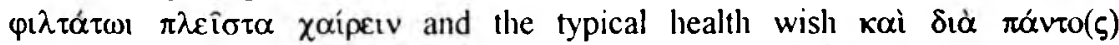

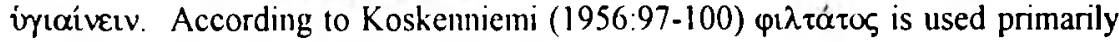
in private letters. However, it does not concern family relationships or any friendship between the writer and reader. The qualification $\tau \hat{\varphi} \varphi \imath \lambda \tau \alpha \dot{\alpha} \omega$ indicates a business letter and is generally not taken to express feeling but an objective. This phrase is very seldom used in letters of friendship - the recipient of a friendly letter is seldom addressed as $\tau \hat{\varphi} \varphi \varphi^{\prime} \lambda \tau \alpha \tau \varphi$. The greeting in this letter is thus not

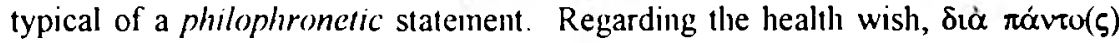
iopoiveıv (line 2-3) is, although a shorter parallel forn, a typical health formula, and according to Koskemiemi (1956:128), the health wish and other statements on the welfare of the recipient are common philophronetic formulae.

\section{* Letter body}

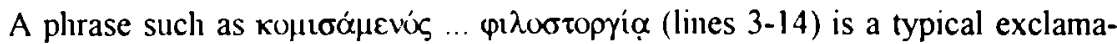
tion of joy at the receipt of a letter (see White, 1986:201). According to White such an exclamation is more characteristic of the opening of a letter. The opening of the letter scems to be the logic part to contain sucl a phrase if one takes the possible function of such a phrase into consideration. A possible function of the

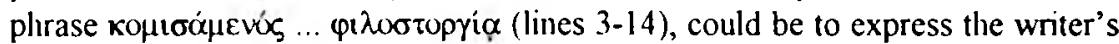
good attitude towards the recipient and to to make sure that the recipient is also positive and ready for the rest of his argument or any innovations. Because lines 3-14 do not, however, only express joy at the receipt of the letter but have an almost philosophical argument about friendship, they may be considered as the opening of the letter body. Although lines 3-14 do not fit into a specific philophronetic fornula or phrase, they seem to fonn some kind of philophronetic paragraph. Chairas describes his joy at receiving Dionysios' letter (lines 3-4) and explains why he has not written sooner (lines 4-14).

In line 14 another subject is dealt with when the writer turns to what the recipient had written in his letter. This subject serves as the background for the advice Chairas is about to ask. Lines 14-20 thus serve as the middle of the letter body. The closing of the letter body is introduced by a typical request such as $\dot{\varepsilon} \omega \omega \hat{\omega}$ (line 20) (see White, 1986:208). 
* Letter closing

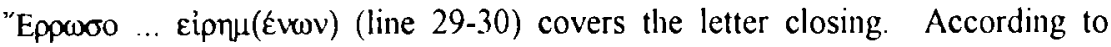
Koskenniemi éppwor (line 29) is a typical philophronetic formula (1956:151). I would like to add to this $\mu \varepsilon \varepsilon \mu \eta \eta \sigma o$ (line 30) as another philophronetic statement.

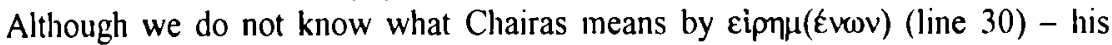
request for advice (lines 17-23), or perhaps his explanation why friends do not thank by words - this statement could correspond to the 'remembrance' formula as expounded by Koskenniemi (1956:145). Chairas could mean that Dionysios should remember him, and could express both his attitude towards their being friends as well as his current need.

\section{* Synthesis}

In this letter to Dionysios, the philophronetic elements are present in all three parts of the letter. Whereas one would expect a lot of philophronetic elements in the opening and closing of the letter body, if one considers the fact that Stowers considers this letter to be of the friendly type, this letter seems to be poor in the

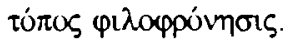

\subsubsection{Excavations of Herculaneum 176: Epicurus to a child (3 B.C.E.)}

This is a letter from Epicurus (the well-known philosopher) to a child (possibly an orphan of a certain Metrodorus, of whom Epicurus took charge). The text and translation are from Milligan (1927:5-6).

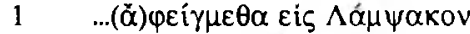

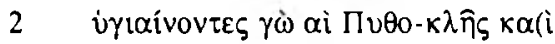

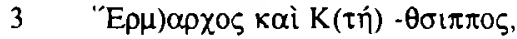

$4 \quad \kappa \alpha i \dot{\varepsilon} \kappa \varepsilon \hat{\imath} \kappa \alpha \tau \varepsilon \imath \lambda \dot{\eta} \varphi \alpha-\mu \varepsilon v$

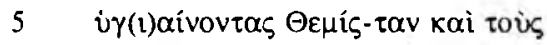

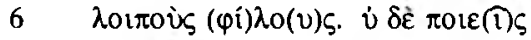

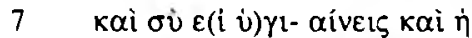

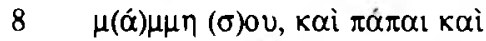

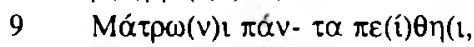

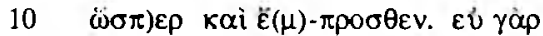

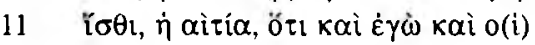

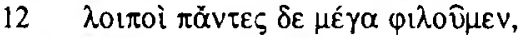

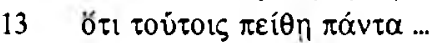

We have arrived in health at Lampsacus, myself and Pythocles and Hermarchus and Ctesippus, and there we have found Themistas and the rest of the friends in health. It is good if you also are in health and your grandmother, and obey your grandfather and Matron in all things, as you have done before For be sure, the reason why both $I$ and all the rest love you so much is that you obey these in all things 


\subsubsection{Formal analysis}

Because this letter is fragmentary, it is uncertain whether the whole belongs to the letter body or whether one can divide it into letter opening and letter body or even letter closing.

\subsubsection{The identification of philophronetic elements}

According to Koskenniemi (1956:133-134) one often finds in the body closing a short 'waming' to the recipient to take care of himself or herself. Typical clichés

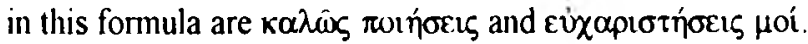

Koskenniemi mentions that the degree of intimacy is determined by what is added to the formula. It is surprising that this infonnation from Koskenniemi exactly describes lines 1-10 of the letter of Epicurus. We get a variation on the cliche

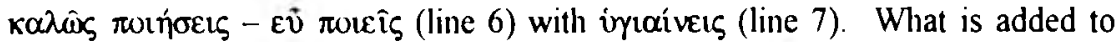
this to make it more intimate, is the same health wish for $\dot{\eta} \mu \alpha \alpha_{\mu} \mu \eta$ - a person near to the recipient and event, a bit of information on the state of health of not only he himself but also of his friends

This letter from Epicurus contains philophronetic elements, but because it is fragnentary, it is not possible to determine to which extent the philophronetic elements dominate.

\subsubsection{Select Papyri I 103: Petesouchos to his brothers and friends (95 B.C.E.)}

This is a letter of Petesouchos to his brothers and friends, consisting of greeting, farewells and assurances of the writer's welfare. The text and translation (on page 66) are from White (1986:54-55)

\subsubsection{The identification of philophronetic elements \\ * Letter opening}

To the letter opening belong greetings and health wishes (White, 1986:198-202).

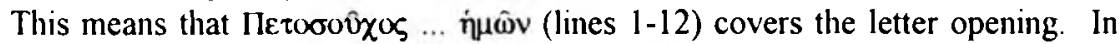
the letter opening we find a health wish - éppwookr (line 8) with the assurance that the writer as well as his friends is well (lines 8-12). Koskenniemi (1956: 132 ) is of opinion that the writer may consider it important to express his interest in things or persons close to the recipient, as part of the health wish. Petesouchos knows his brothers and friends well enough to know exactly what and who are of great importance to them. This enables him to show that they have mutual inte- 
rest in these persons. The extensiveness of the health wish in the letter from Petesouchos thus reveals something of the kind of relationship between Petesouchos and his friends.

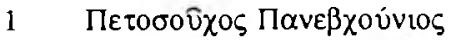

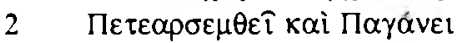

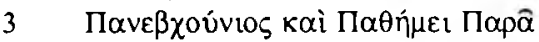

$4 \quad \kappa \alpha \grave{~} \Pi \varepsilon \tau \varepsilon \alpha \rho \sigma \varepsilon \mu \theta \varepsilon \hat{\imath}$

5 'A

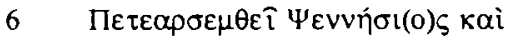

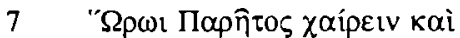

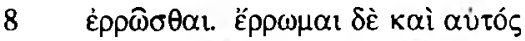

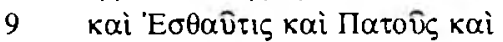

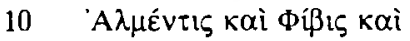

$11 \Psi$ I

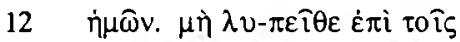

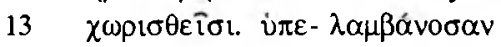

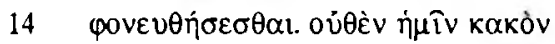

$15 \dot{\varepsilon} \pi u ́ \eta \sigma \varepsilon v, \dot{\alpha} \lambda \lambda^{\prime} \dot{\varepsilon} \kappa \tau \widehat{\omega} \nu \dot{\varepsilon}^{\prime} v \alpha v \tau i \omega \nu$

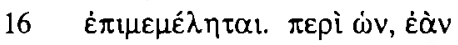

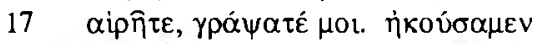

18 tòv $\mu$ Uิv $\kappa \alpha \tau \alpha-\beta \varepsilon \beta \rho \omega \kappa \varepsilon ́ v \alpha$ tòv

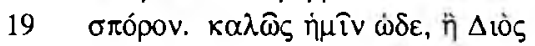

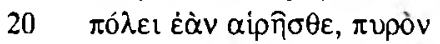

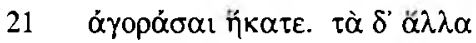

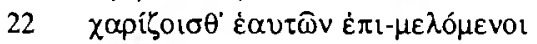

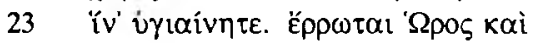

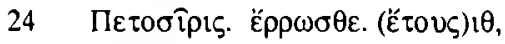

$25 \Pi \alpha \chi \omega \nu \eta$.

Petosouchos, son of Panebchounios, to Peteharsemtheos and Paganis, sons of Panebchounios, and Pathemis, son of Paras, and Peteharsemtheos, son of Harsenouphis, and Peteharsemtheos, son of Psennesis, and Horos, son of Pates, greeting and good health. I myself am also well, along with Esthautis and Patous and Almentis and Phibis and Psenosiris and Phaphis and all our people Do not be grieved at the deparned ones. They were expected to be killed. He did nothing bad to us but, quite to the contrary, he has taken care of us. Concerning this matter, if you want, write to me We heard that the mice have eaten up the crop Please come here to us or, if you prefer, to Diospolis to buy grain For the rest, you would favour us by taking care of yourselves that you stay healthy. Horos and Petosiris are well. Good-bye. (Year) 19, Pachon 8

Outside address: To Peteharsemtheos the son of Nebchounios. From Petesouchos, the son of Nebchounios.

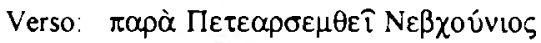

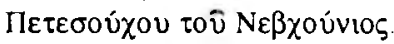

\section{* Letter body}

White (1986:208) identifies lines 12-16 ( $\mu \dot{\eta} \ldots \dot{\varepsilon} \pi \mu \mu \mu \varepsilon \hat{\varepsilon} \eta \eta \alpha \alpha)$ as the opening of the letter body, introduced by non-formulaic instructions. It is, however, remarkable that these instructions also concern consolation and reassurance about mutual matters.

According to White (1986:211), the phrase $\pi \varepsilon \rho$ i with the genitive $\omega v$ (line 16) is sometimes used in the middle of the letter body but more often at a later point in the body than at the very beginning. In this case it, however, seems that the prepositional phrase $\pi \varepsilon p i$ with the genitive $\dot{\omega} v$, introduces the middle of the letter body ( $\pi \varepsilon \rho i$... clear that Petesouchos is worried about the apparent bad circumstances of the 
recipients (lines 16-19) and that he would like to share in seeking a solution (lines 19-21).

Concluding the letter body, Petesouchos asks the recipients to take care of

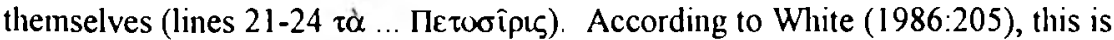
a typical formula for concluding the letter body. Petesouchos, however, extends

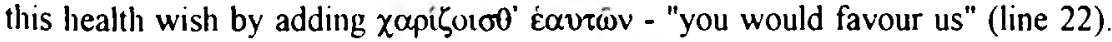
This extension of the health wish increases the intimacy between parties (Koskenniemi, 1956:134).

\section{* Letter closing}

The letter is closed with the typical greeting fonnula expowote (line 24), which is a philophronetic element as such (see 2.1).

\section{* Synthesis}

In this letter from Petesouchos almost the whole letter consists of philophronetic elements. The letter opening as well as the letter closing contains typical philophronetic elements (as discussed by Koskenniemi, 1956:128-154). The letter body on the other hand is a complete discussion of mutual interests and care

\subsubsection{Conclusion}

The letters from Dionysios (PMert I 12) and Epicurus (Ex Hercul 176) do contain philophronetic elements, but only minimally so. In the letter from Petesouchos to his brothers and friends (SelPap 1 103), almost the whole letter consists of greetings and statements conceming welfare and love. This can be ascribed to the fact that the purpose of this letter is only to express friendship.

What do all the philophronetic statements have in common? I concur with Koskenniemi (1956:132) that the health wishes probably concem matters of importance to the recipient. The analysis above would seem not only to confirm this point, but also to conclude that all philophronetic elements serve to make the recipient feel good about himself.

To persuade by means of $\pi$ ó $\theta$ os means to use statements about those things that are important to the recipient, in order to arouse feelings of pity, sorrow, sympathy or compassion. In the first letter, Chairas writes about his joy when receiving his friend's letter and wishes him health. These statements are used in the letter opening, body opening as well as in the letter closing, to make Dionysios open-minded with regard to the request in the middle of the letter body, namely the request for advice. 
In the second letter, Epicurus is most concened about the child's health and actions. Whatever Epicurus wants to achieve, these statements are still everything the child likes to hear.

In the third letter all the greetings, the farewell and assurances of the writer's welfare serve the function of $\pi$ átos.

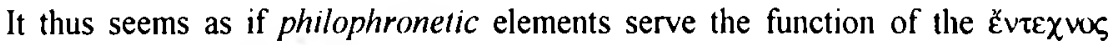

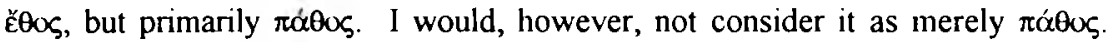
Petersen (1985:53) states the obvious fact that letters are surrogates for the personal presence of the addresser with the addressee. According to Petersen, Koskenniemi has demonstrated that the letter's fundamental structure reflects what happens in the face-to-face meeting of friends. And, Petersen continues, a letter thus functions to establish or maintain a relationship when the parties cannot meet in person.

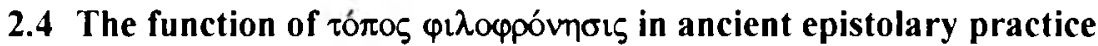

\subsubsection{The position of philophronetic elements as an indicator of the

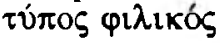

According to Koskenniemi (1956:94) one must take into account that the common epistolary style also contains philophronetic elements (not only the friendly letter). But is there a difference in the use of philophronetic statements in a friendly letter and in a letter of recommendation?

In letter types other than that of friendship, one would expect the philophronetic elements to be only part of the letter opening and closing, whereas in friendly letters it is expected to be also part of the letter body. And the more the purpose of a letter is to express friendship, the more philophronetic elements will appear in the letter body. If the purpose is simply to express friendship, one would expect philophronetic elements also in the middle of the letter body. It is, however, important to keep in mind that other types of letters may also contain philophronetic elements in the letter body. This may be an indicator of a mixed type of letter.

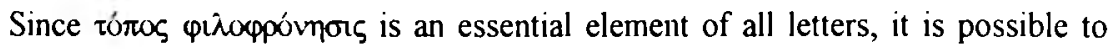
determine on the basis of the position of philophronetic elements whether the letter fits into the friendly type or not. 


\section{An analysis of the letter to the Philippians}

\subsection{The integrity of Philippians}

The problem surrounding the integrity of Philippians handicaps a formal analysis of Philippians. Although we have Philippians as one letter in UBS III, it is important for a study on ancient letters to consider it in its original form.

Kümmel (1965) and Garland (1985) discuss the whole matter. According to some, the transmitted letter to the Philippians has secondarily been compiled by joining two or three originally independent epistles or fragnents of letters. Advocates of this view point out that Paul in Philippians, until 3:1, offers the paragon of a clear and precise letter, but that in 3:1 an epistolary conclusion begins which is interrupted in $3: 2$ by a warning, while $4: 4$ connects very well with $3: 1$. On the basis of these considerations some critics suppose that $3: 3-4: 3$ is an interpolation. Other critics find that the thanks for the gift of the Philippians $(4: 10-20)$ is also out of place at the end of the letter. Moreover, 3:2-4:3 presupposes no imprisomment of Paul.

As a result, we have the view that Philippians is composed of three letters, each chronologically following upon the previous one (Kümmel, 1965:235). Because of this problem modem theorists also have difficulty in dealing with the letter. In his analysis of the letter, White (1972:73-90) ignores 2:25-4:9.

For Kümmel (1965:237), however, there is no sufficient reason to doubt the original unity of the transmitted Philippians. Garland (1985:143) is of opinion that the arguments against the integrity of the letter are just as plausible as the counter-arguments and he describes this debate as a 'stalemate' in argumentation.

Watson (1988) analyses Philippians rhetorically in order to address the unity question. He (Watson, 1988:88) concludes his article by the following assumptions:

* If the partition is maintained, one must assume that the host letter and the interpolated letters were redacted so that the rhetoric of the whole has been unified in the present form.

* Since the present form of Philippians conforms well to the classical rhetorical conventions, the integrity can be assumed.

Although I am of opinion that Watson uses the rhetorical perspective incorrectly to analyse a letter formally, this article is a proof of the fact that the debate on the integrity of Plilippians has certainly reached stalemate. It is, however, beyond the limits of this article to survey this discussion in detail. For the purpose of this 
article it can be assumed that Philippians as we have it today, is a single unit and can be interpreted as such.

\subsection{The identification of philophronesis in Philippians}

\section{* Letter opening}

The letter opening consists of a salutation in 1:1-2 and a thanksgiving in 1:3-11.

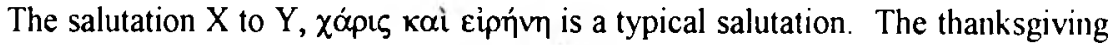
is also introduced by the typical phrase e $\chi_{\chi \alpha \rho} \sigma \tau \hat{\omega}(1: 3)$.

1:3-11: The conventional proskynema formula is something like $\pi \rho \dot{o} \mu \grave{\varepsilon} v$

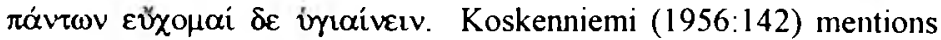
that in the fourth century and later, the proskynema fonnula lost its original form. This coincides with the expansion of Christianity and as a result 1:3 introduces a typical proskynema formula, $\varepsilon \dot{x} \chi \alpha \rho, \sigma \tau \hat{\omega} \tau \hat{\omega} \theta \varepsilon \hat{\omega} \mu \nu$... Except for the formula, the whole letter

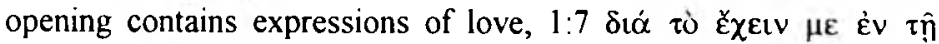

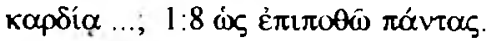

\section{* Letter body}

The letter body of the letter to the Philippians is introduced by the typical formula

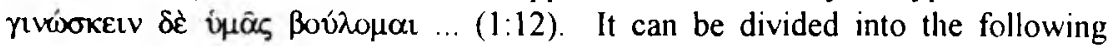
parts:

Body opening: $1: 12-26$

Body middle: $\quad 1: 27-4: 9$

Body closing: $\quad 4: 10-20$

In the middle of the letter body Paul switches from $I$ to the you (1:27). This can be considered as the transition from the opening of the body to the middle. The middle of the letter body is in 2:19-30, interrupted by the information about $\mathrm{Ti}$ mothy.

\section{* Letter body: opening:}

1:12-26: Following upon the thanksgiving, this is an autobiographical para-

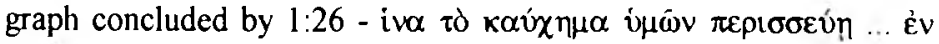
$\dot{\varepsilon} \mu$ oì ... This paragraph can be considered as another example of

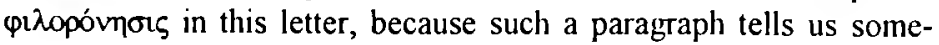
thing about the nature of the relation between Paul and the Philippians. Paul expresses his concern for their well-being, their growth in faith and joy. 
* I.etter body: middle:

2:17-18: Stowers (1986:60) considers "sharing in one another's feelings"

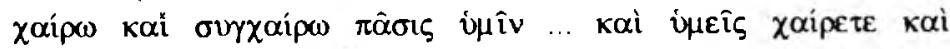

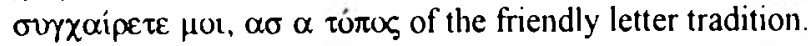

2:19-30: This whole paragraph I consider as an example of pituxpoummors, because Paul gives some information to the Philippians concening the mutual friends Timothy and Ephaphrodite. It is clear that both

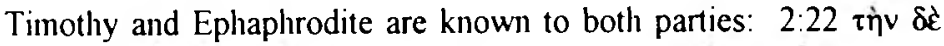

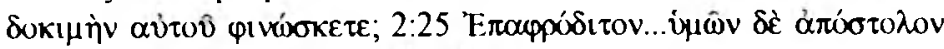

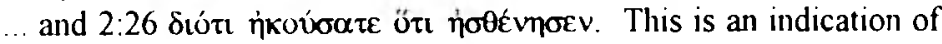
their kind of relationship and of their concern for each other. They send mutual friends to each other because of their concern for each other.

* Letter body: closing:

$4: 10$

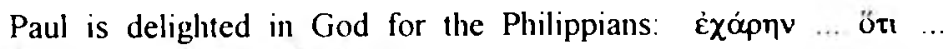

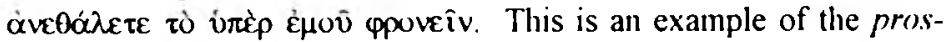
kynema fonmula. By using this fonmula, Paul refers to the good characteristics of the recipients. He actually thanks them for their caretaking. It is evident that the writer and the recipients have a special relation.

\section{* Letter closing:}

The letter closing is covered by $4: 21-23$. This part of the letter offers a switch to the $I$ again $(4: 10)$ and contains the typical secondary greetings $(4: 21)$ and blessings $(4: 23)$.

4:21-22: Typical of pitoxpómmors are the greetings and secondary greetings

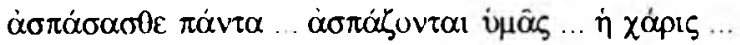

\section{* Synthesis}

From the analysis of Philippians it is clear that Paul uses pizoxpóvmois in every part of the letter. This, however, does not seem to make of Philippians a túnos

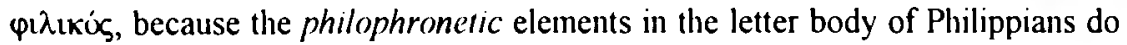
not dominate when one realizes the extensiveness of the letter body.

The whole opening of the body of the letter to the Philippians is an example of

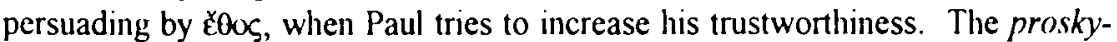
nema fonnulae in the letter opening and closing of the letter body are examples of persuasion by means of $\pi \dot{\alpha} \theta 0 \alpha_{5}$. Another example of $\pi \dot{\alpha} \theta 0 \varsigma$ is found in the middle of the letter body, when Paul talks about feelings to be shared. All these exam- 
ples arouse the readers' emotions and make them open-minded with regard to the information given in the rest of the letter body.

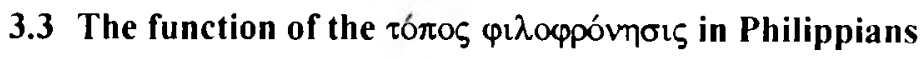

It seems as if one may be able to determine from the philophronetic elements the nature of the relationship between writer and recipient. With the help of the following fundamental theses illustrated by Petersen (1985:63-64), this relationship will be made clear:

* Every letter constitutes a new moment or event in the relationship.

* Every letter implies at least one future stage in the relationship.

* The persons referred to in the letters are related to one another in some way in terms of role, position or status.

* The rhetoric, style and tone of a letter correspond to the addresser's perception of his or her status in relation to the addressee.

From this it should be clear that by reading and interpreting the philophronetic elements, one will perhaps be in a better position when attempting to read also between the lines. By studying $\varphi \mathbf{t}$ oxpóvmois in Philippians, for example, one can catch a glimpse of what the relationship between Paul and the Philippians

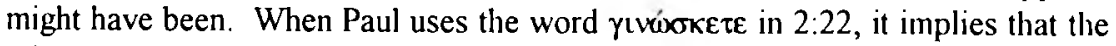
relationship between him and the readers is an already existing relationship which

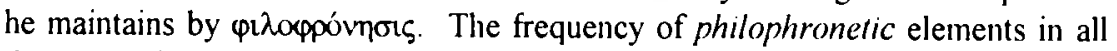
the parts of the letter is an indicator of a high degree of intimacy between Paul and the Philippians.

\section{Conclusions}

The following can be concluded:

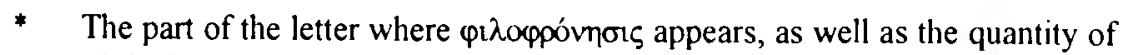

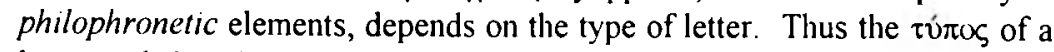

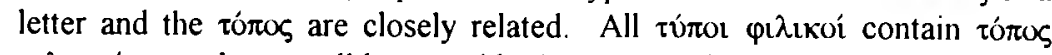

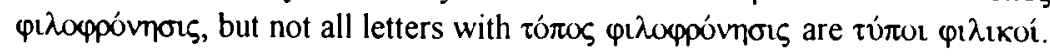

* What is added to the typical philophronetic elements increases the degree of intimacy between the addresser and addressee.

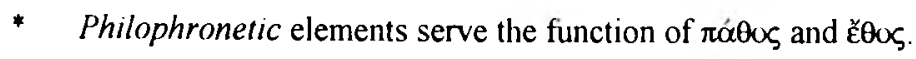

* An analysis of philophronetic elements can shed light on aspects of the nature of the relationship between addresser and addressee.

* The letter to the Philippians also employs philophronetic elements. 
* The function of the philophroneric elements in Philippians function as ró $\theta 0$ s and čoos and it is no indication of a friendly letter type

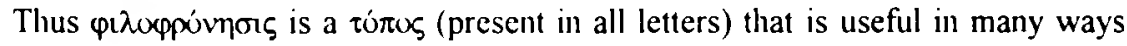
for the writer of a letter. Studying $\varphi$ inoppóvmois in letters also enables one to see something about the writer's means of persuasion, the type of letter and the relationship between addresser and addressee.

\section{Bibliography}

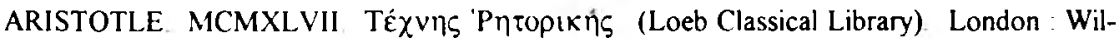
liam Heinemann

DAHL, N. 1976 Letter ( $/ / 1$ The Interpreter's Dictionary of the Bible, Supplementary volume. Nashville Abingdon p 538-540)

DOTY, W G 1983. Letters in Primitive Christianity Philadelphia Fortress Press

GARLAND, D 1985. The Composition and Unity of Philippians Novum Testamentum, 27. 141-173.

KOSKENNIEMI, H 1956 Studien zur Idee und Phraseologie des Griechischen Briefes bis 400 n Chri Helsinki : Suomalaisen Kirjallisuuden Kirjapaino

KuMMEL, W G 1965 Introduction to the New Testament London: SCM Press

MALHERBE, A J 1988 Ancient Epistolary Theorista Georgia : Scholars Press.

MILligAN, G 1927 Selections from the Greek Papyri Cambridge : University Press

MURPHY, J J 1972 A Synoptic History of Classical Rhetoric New York: Random House

PETERSEN, N.R. 1985. Rediscovering Paul Philadelphia : Fontess Press

QUINTILIAN 1947. Imstimtio ()ratoria (Loeb Classical Library) London: William Heinemann

STOWERS, S K 1986 Letter W'riting in Greco-Roman Antiquity Philadelphia : The Westminster Press

WATSON, D F 1988 A Rhetorical Analysis of Philippians and Its Implications for the Unity Question Noivum Testamenum, 30:57-88

WHITE, J.L 1972. The Form and Function of the Body of the Greek Letter in Non-Literary Papyri and in Paul the Apostle Michigan Edwards Brothers, Inc

WHITE, J L 1986 Light from Ancient Letters (Foundations and Facets New Testament) Philadelphia Fortress 
